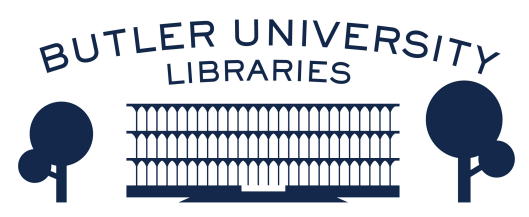

Journal of Hindu-Christian Studies

Volume 12

Article 12

January 1999

\title{
Book Reviews: "Inkuluration in Tranquebar" and "Brahmabandhab Upadhyay"
}

Francis X. Clooney

Follow this and additional works at: https://digitalcommons.butler.edu/jhcs

Part of the Religion Commons

\section{Recommended Citation}

Clooney, Francis X. (1999) "Book Reviews: "Inkuluration in Tranquebar" and "Brahmabandhab Upadhyay"," Journal of Hindu-Christian Studies: Vol. 12, Article 12.

Available at: https://doi.org/10.7825/2164-6279.1210

The Journal of Hindu-Christian Studies is a publication of the Society for Hindu-Christian Studies. The digital version is made available by Digital Commons @ Butler University. For questions about the Journal or the Society, please contact cbauman@butler.edu. For more information about Digital Commons @ Butler University, please contact digitalscholarship@butler.edu. 


\section{BOOK REVIEWS}

\section{Inkulturation in Tranquebar: Der Beitrag der frühen dänisch- halleschen Mission zum Werden einer indisch-einheimischen} Kirche (1706-1730). Daniel Jeyaraj. Erlangen: Verlag der Ev.-Luth. Mission, 1996, xiv $+367 \mathrm{pp}$.

\section{Brahmabandhab Upadhyay: The Life and Thought of a Revolutionary. Julius J. Lipner. Delhi: Oxford University Press, 1999, xxiv + $409 \mathrm{pp}$.}

THE MORE WE find out about the long and varied interaction of Hindus and Christians in India, the more there is to learn. Probably the most complicated and bittersweet period in this encounter is during the time of European colonial dominance in India. Even now, more than fifty years after Independence, Christians and Hindus are still sorting out and beginning to come to terms with this mixed heritage, trying to make sense of what it means to be a religious Indian and, indeed, a Christian or Hindu of any nationality with this history still defining who we are. We can rightly be edified by the many selfless acts of generosity and service on the part of European Christians coming to India but we should also be dismayed by missionary condescension or outright hostility toward Indian faiths, which they often barely understood. So too, we are increasingly cognisant of how the history of missions is not simply the history of Europeans in India, but, increasingly over time, also the story of Indians who chose or declined to become Christian. Conversion was the measure of success, the goal, and also the key point of controversy. But how was it actually promoted and what did it mean for individuals faced with the possibility?

The two splendid books under review here are thoughtful, scholarly studies which from different perspectives advance our understanding of the context and dynamics of conversion. Daniel Jeyaraj, Professor at the Lutheran Gurukkul in Chennai, has focused on a larger picture, the origins and early development of the German-Danish mission in Tranquebar, in the Tanjore district of Tamil Nadu, South India. This mission began with the arrival of the Lutheran missionaries Bartholomaus Ziegenbalg (1682-1719) and Heinrich Pluetschau (1677-1746) in Tranquebar in 1706 , an arrival which initiated the long and rich history of Evangelical Christianity in India. Jeyaraj studies it just through its first decades, choosing significantly to stop with the ordination in 1733 of the first Indian pastor in the mission, a man from the vellala caste named Aaron. After surveying archival sources and the history of scholarship regarding the mission, Jeyaraj devotes a long and interesting chapter to the missionaries' initial encounters with south Indian culture, as they started to learn about the Hindu traditions and put into writing their thoughts on Hinduism (most famously in Ziegenbalg's Genealogy of the Hindu Gods). We learn about their efforts to master the Tamil language and translate the Bible into Tamil. Of particular interest is the missionary exploration of "Tamil ethics"; Ziegenbalg wrote several Tamil treatises on this topic and also reported his findings back home, and Jeyaraj uncovers interesting research possibilities regarding this early theorizing on cross-cultural ethics and the missionary use of ethical materials. The book's third section is equally fresh and 
illuminating, a narrative of the effort to found an indigenous church in the face of conflicts: among the missionaries themselves on what this Christian community should be like (e.g. with or without caste distinctions); with Hindus (on political and religious grounds); and of course with the Jesuits already well-established in Tamil Nadu. Jeyaraj wisely moves beyond purely textual study, examining church architecture, Tamil Christian music, poetry, and liturgical forms, and educational and catechetical programs. We come away from this book with a strong sense of the missionary program and the considerable efforts made to give conversion human and cultural depth. Perhaps because the sources do not exist, we do not learn much, however, on Hindu responses to the mission. A scholarly achievement, Inkulturation in Tranquebar is a personal endeavour for the author, a scholar also seeking his spiritual roots; in the preface he tells us that his interest in Christian history in south India was sparked by his own study of the Bible and decision to become a Christian in 1980 .

It is certainly hard to sort out the complex layers and contours of a missionary project, but Julius Lipner, lecturer in Indian and Comparative Religion at the University of Cambridge, reminds us how complex it can be to probe the mind and heart of a single convert, particularly one so interesting and highly articulate as the gifted Bhabanicharan Bandyopadhyay (18611907), better known by his self-selected Christian name, Brahmabandhab (a Bengali rendering of "Theophilus", premised on the belief that St Theophilus was the first to write about the mystery of the Trinity). Lipner does a masterful job in piecing together the surviving Bengali and English sources which illuminate what Brahmabandhab was doing and thinking at each stage in his life. Brahmabandhab - a wellknown writer, educator, journalist, public speaker, rebel - was also a searching soul who spent much of his life looking for a spiritually satisfying and intellectually credible religious home. After various experiments with reform Hindu groups (for a time he was a follower of Keshab Chander Sen and a member of the Church of the New Dispensation) and Protestant Christianity, he settled on Roman Catholicism, judging that its intellectual tradition offered the best religious vantage point from which to integrate and revivify Indian religious life. The chapters appropriately mark the stages of Brahmabandhab's life with images of fire - "crucible", "ember", "fire-eater", "flame", "flicker", "consuming passion". Indeed, although Brahmabandhab's faith seemed always as fragile as a smouldering wick, he was quite capable of brilliance and did not hesitate to scorch foes (ranging from lethargic traditionalists to timid reformers and visiting theosophists as well). Lipner rightly focuses on Brahmabandh's conversion, his necessarily complex choice and its accompanying assessments of the state of traditional and reformed Hinduism in his time, the current needs of Bengal and India, the status of Christianity as a universal but also European religion, the delights of Thomism, and what it meant to be a follower of Christ - in simple, personal encounter, but also as a member of some established church community. An ardent follower of Christ, he was never content with standard church membership. Even after his baptism, he wisely and stubbornly insisted that his Christian identity was. still that of an Indian devoted to his own culture and zealous for the freedom and renewal of his country. At the end of his life Brahmabandhab seemed still content with a blurred boundary between Hindu and Christian identities. His public seemed to accept this too, since his funeral was a Hindu one, despite Catholic hopes of retrieving his body.

These excellent books enrich our understanding of conversion as corporate strategy and personal choice, and together they ably dispel temptations either to vilify or romanticize missions and conversions. One wishes for ten more studies like each of these - but even then the picture would not be complete, since we would still be looking at just one side of the coin, the Christian project and what happened to Indians who 
accepted the call to become Christian. We need to learn more about Hindu individuals who did not show interest in Christianity and chose not to convert, and likewise the communal ways in which Hindu communities reaffirmed their identities in the face of Christian missionary efforts. While we are grateful for the published works of scholars and journalists - e.g. Richard Fox
Young's Resistant Hinduism, Arun Shourie's Missionaries in India - we need many more historical studies which illuminate the resistance and resilience of Hinduism, the other side of the encounters and choices so well presented by Jeyaraj and Lipner.

Francis X. Clooney, SJ Boston College

\section{Beyond the Darkness: A Biography of Bede Griffiths. Shirley Du} Boulay. London: Random House / New York: Doubleday, 1998, 308 pp.

BEDE GRIFFITHS (1906-1993), an English Benedictine monk, went to India in 1955. There, continuing the project of Jules Monchanin and Henri Le Saux (Abhishiktananda), Griffiths would become a pioneer in the development of an Indian-Christian monastic life incorporating elements of Hindu monastic life and liturgy. Shirley Du Boulay's excellent biography complements Griffiths' own extensive writings by enabling us to follow, step by step, the unfolding of his life and thought at the frontier of East and West.

Bede Griffiths' central concern with the encounter of religions, and especially with the meeting between Christianity and Hinduism, is evident in the titles of six of his books: Christ in India (1966), Vedanta and Christian Faith (1973), The Marriage of East and West (1983), The Cosmic Revelation: The Hindu Way to God (1983), River of Compassion: A Commentary on the Bhagavad Gita, (1987), The Universal Wisdom (1994).

Already in the 1930s, Griffiths had grasped the importance of the Hindu, Buddhist, and Daoist Scriptures for the future of Christianity. In India, he said, he sought and found the other half of his soul. Very soon, in the cave sculptures of Elephanta, he recognized what he had come to India to find, the contemplative dimension of life which had almost disappeared from the West, "that hidden depth of existence, springing from the depth of nature and the unconscious and going beyond into the mystery of the infinite and eternal" (110-11).

Bede rejected both the traditional proselytism of Christian missionaries and a facile syncretism that would ignore the essential differences between the great religious traditions. At the same time he was profoundly convinced of the ultimate unity of religions; he would conceive this relationship more and more in terms of the complementarity of different traditions.

By the 1950s, the "Perennial Philosophy" was emerging at the centre of Bede's thought as the common core of all religions: a unitive metaphysical vision which he found most explicit in the Upanishads, but represented also in the West by Plotinus, Plato, Aristotle, and Aquinas. In the following decades this "universal tradition" would be more and more clearly identified with nonduality, the advaitan reality. A second, closely related, principle of the Vedanta became equally central for Griffiths: the search for the "Self", or Atman.

By 1971 Griffiths would write to a friend, "To me Eastern wisdom gives the key to Christianity. I cannot conceive of Christ now except in terms of Vedanta". (181). He continued to seek opportunities and to encourage encounters for HinduChristian dialogue. At his Saccidananda Ashram (better known as Shantivanam), in Tamil Nadu, thousands of westerners would experience the meeting of the two traditions.

Griffiths' vision is set forth in ten 